\title{
ANALISIS STRATEGI PENGEMBANGAN PARIWISATA KAWASAN SELAT LEMBEH DI KOTA BITUNG
}

\author{
Ellen R. Sutrisno \\ Charles R. Ngangi \\ Caroline B. D. Pakasi
}

\begin{abstract}
This study aims to analyze the strategy of tourism development of Lembeh Strait Region in Bitung City. The study was conducted in the Lembeh Strait Area of Bitung City, which covers the Lembeh Island region and the mainland of Bitung City. The study took place in March 2018. This research used kuantitatif descriptive method. The data source consists of primary data and secondary data. Primary data is obtained directly from the field through the respondents who have been determined, while secondary data obtained from agencies or institutions related institutions such as the Tourism Office, BPS Bitung, libraries and other relevant SKPD ie Tourism Office, Bappeda, Investment and One Stop Service Office. Sample collection used technique of Accidental and Purposive Sampling. Data collection technique used in this research is Field Survey. Researchers prepare and retrieve data through surveys, questionnaires, document studies, interviews, documentation. This study uses SWOT data processing analysis through process analysis of Internal factors and External factors. The result of this research shows that the strategy of tourism development of Lembeh Strait area in Bitung City based on SWOT analysis is in the first quadrant between external opportunity and internal strength where the result of analysis obtained by total score of Internal Factor Analysis (IFAS) is 3.076 and External Factor Strategic Analysis Summary (EFAS) is 3.396. The main strategy in developing Lembeh Strait area tourism that must be implemented is to develop and improve the factors of Attraction, Accessibility and Amenities as follows: (1) Maintaining the beauty and uniqueness of nature Lembeh Strait as the main Attraction and adding new artificial attraction object; (2) Completing and improving public facilities and tourism facilities and facilities and infrastructure; (3) Make intelligent use of social media communication information technology as a cheap and efficient means of promotion. *eprm*.
\end{abstract}

Keywords: analyze the strategy, SWOT, tourism development, Lembeh Strait Region, Bitung City

\begin{abstract}
ABSTRAK
Penelitian ini bertujuan untuk menganalisis strategi pengembangan pariwisata Kawasan Selat Lembeh di Kota Bitung. Penelitian dilakukan di Kawasan Selat Lembeh Kota Bitung, yang meliputi wilayah Pulau Lembeh dan daratan Kota Bitung. Waktu penelitian berlangsung pada bulan Maret 2018. Penelitian ini menggunakan metode deskriptif. Sumber data terdiri dari data primer dan data sekunder. Data Primer diperoleh langsung dari lapangan melalui responden yang telah ditentukan, sedangkan data sekunder diperoleh dari instansi atau lembaga - lembaga yang terkait seperti Dinas Pariwisata, Badan Pusat Statistik (BPS) Bitung, perpustakaan dan SKPD terkait lainnya yaitu Dinas Pariwisata, Bappeda, Dinas Penanaman Modal dan Perijinan Satu Pintu Kota Bitung. Penentuan sampel menggunakan teknik Accidental dan Purposive Sampling. Teknik pengumpulan data yang digunakan dalam penelitian ini adalah Survey Lapangan. Peneliti melakukan persiapan dan pengambilan data melalui survey, kuesioner, studi dokumen, wawancara, dokumentasi. Penelitian ini menggunakan analisis pengolahan data SWOT melalui proses analisis terhadap faktor Internal dan faktor Eksternal. Hasil penelitian menunjukkan bahwa strategi pengembangan pariwisata kawasan Selat Lembeh di Kota Bitung berdasarkan hasil analisis SWOT berada di kuadran pertama antara peluang eksternal dan kekuatan internal dimana hasil analisis diperoleh nilai skor total Internal Factor Strategic Analysis Summary (IFAS) adalah 3,076 dan External Factor Strategic Analysis Summary (EFAS) adalah 3,396. Strategi utama dalam mengembangkan pariwisata Kawasan Selat Lembeh yang harus dilaksanakan adalah dengan mengembangkan dan meningkatkan faktor Atraksi, Aksesibilitas dan Amenitas sebagai berikut: (1) Menjaga Keindahan dan keunikan alam Selat Lembeh sebagai daya tarik utama dan menambah objek daya tarik buatan yang baru; (2) Melengkapi dan meningkatkan fasilitas umum dan fasilitas pariwisata serta sarana dan prasarana yang ada; (3) Memanfaatkan dengan cerdas teknologi informasi komunikasi sosial media sebagai sarana promosi yang murah dan efisien.*eprm*.
\end{abstract}

Kata kunci: analisis strategi, SWOT, pengembangan pariwisata, Kawasan Selat Lembeh, Kota Bitung 


\section{PENDAHULUAN}

\section{Latar Belakang}

Pembangunan pariwisata yang merupakan program unggulan dalam pembangunan Nasional Indonesia diharapkan mampu mendorong pertumbuhan ekonomi Nasional disamping sektor migas dan pajak. Untuk mencapai tujuan tersebut maka sektor pariwisata harus digerakan dan diberdayakan baik ditingkat nasional maupun daerah secara optimal.

Sejalan dengan pemerintah pusat, pemerintah Provinsi Sulawesi Utara juga menjadikan pariwisata sebagai salah satu prioritas pembangunannya. Untuk suksesnya program ini maka perlu ditunjang oleh kabupaten /kota yang ada mengingat destinasi pariwisata berada dalam wilayah geografis dan pemerintahan kabupaten/kota.

Kota Bitung dengan berbagai potensi pariwisata yang unik dan bernilai jual tinggi, berkewajiban untuk menunjang program pemerintah disektor pariwisata melalui pengembangan destinasi pariwisata untuk meningkatkan jumlah kunjungan wisatawan. Berdasarkan Peraturan pemerintah No 50 tahun 2011 tentang Rencana Induk Pembangunan Pariwisata Nasional telah ditetapkan Selat Lembeh sebagai kawasan strategis pariwisata Nasional. Kawasan Selat Lembeh menjadi salah satu primadona pariwisata di Kota Bitung dan tujuan wisata bagi para pecinta diving/diver baik nasional maupun internasional. Keunikan Selat Lembeh dengan keindahan pemandangan alamnya juga dikenal sebagai sebagai "Muck Diving" terbaik dengan keunikan biota lautnya yang hanya ada dan hidup berkembang biak di Selat Lembeh sehingga menjadi surga Macro Photography bawah laut yang menjadi daya tarik bagi para divers domestik dan mancanegara. Disamping keindahan dan keunikan alam, daya tarik pariwisata kawasan Selat Lembeh juga dilengkapi dengan beberapa atraksi buatan seperti Patung Yesus memberkati dan monumen Trikora sebagai situs bersejarah. Memperhitungkan berbagai potensi pariwisata yang ada di kawasan Selat Lembeh, maka pemerintah kota Bitung berkewajiban untuk mengembangkan pariwisata yang ada dengan berbagai strategi.

Trend peningkatan jumlah kunjungan wisatawan yang terus meningkat dari tahun ketahun serta tingginya minat investasi bidang pariwisata di kawasan Selat Lembeh menunjukkan kawasan pariwisata Selat Lembeh dapat menjadi tujuan pariwisata yang lebih unggul yang memberikan manfaat lebih bagi pemerintah dan masyarakat. Hal ini dapat tercapai apabila kawasan tersebut dikelola secara lebih baik dan profesional untuk meningkatkan daya tarik pariwisata yang nantinya dapat menjadi salah satu objek atau atraksi parwisata andalan dalam meningkatkan kunjungan wisatawan di daerah ini.

Berkembangnya pariwisata mendatangkan banyak manfaat bagi suatu daerah yakni secara ekonomi, sosial dan budaya. Perlu peran serta pemerintah, swasta dan masyarakat didalamnya untuk menggerakkan pembangunan pariwisata sejak dalam proses perencanaan dan pelaksanaan untuk menjamin pengembangan pariwisata yang dilaksanakan berkembang dengan baik dan berkelanjutan serta mendatangkan manfaat bagi pemerintah dan masyarakat dengan meminimalisasi dampak yang ditimbulkan. Agar pengembangan pariwisata kawasan Selat Lembeh dapat memberikan manfaat yang sebesar - besarnya bagi pemerintah dan masyarakat maka dalam pelaksanaannya dibutuhkan arahan yang terencana secara sistematis dengan strategi terbaik terhadap potensi yang ada guna meningkatkan jumlah kunjungan wisatawan. Untuk itulah maka dipandang perlu untuk dilakukan penelitian terhadap Pengembangan Pariwisata Kawasan Selat Lembeh di Kota Bitung.

\section{Rumusan Masalah}

Berdasarkan uraian latar belakang diatas, maka rumusan masalah dalam penelitian ini adalah: Bagaimana strategi pengembangan Pariwisata Kawasan Selat Lembeh di Kota Bitung.

\section{Tujuan Penelitian}

Menganalisis strategi pengembangan pariwisata Kawasan Selat Lembeh di Kota Bitung melalui analisis terhadap faktor eksternal dan internal.

Manfaat Teoritis

1. Memberikan kontribusi ilmiah, pengetahuan dan pengalaman dalam mengkaji dan mengembangkan pariwisata.

2. Sebagai bahan literatur untuk kajian penelitian dan pengembangan pariwisata bagi peneliti selanjutnya.

Manfaat Praktis

1. sebagai salah satu strategi dalam menyelesaikan berbagai masalah yang berhubungan dengan pengembangan daya tarik pariwisata di kawasan Pariwisata Selat Lembeh.

2. Sebagai bahan masukan kepada Pemerintah Kota Bitung dalam mengembangkan pariwisata di Kota Bitung. 


\section{METODE PENELITIAN}

\section{Tempat dan Waktu Penelitian}

Penelitian dilakukan di kawasan Selat Lembeh Kota Bitung, yang meliputi wilayah pulau Lembeh dan daratan Kota Bitung. Waktu penelitian berlangsung pada bulan Maret 2018.

\section{Jenis Penelitian}

Jenis penelitian menggunakan metode deskriptif, yaitu dengan cara data dikumpulkan, dianalisis dan dideskripsikan dengan menggunakan pendekatan kuantitatif. Data kuantitatif berupa angka-angka seperti jumlah pengunjung yang datang ke berbagai objek wisata di Pulau Lembeh dan nilai bobot, ratting serta skor. Sumber data terdiri dari data primer dan data sekunder. Data Primer diperoleh langsung dari lapangan melalui informan yang telah ditentukan, sedangkan data sekunder diperoleh dari instansi atau lembaga - lembaga yang terkait seperti dinas Pariwisata, BPS, perpustakaan dan SKPD terkait lainnya.

\section{Penentuan Responden}

Penentuan sampel menggunakan teknik Accidental dan Purposive Sampling . Teknik Accidental Sampling untuk mendapatkan data dari wisatawan yang bertemu secara kebetulan di lokasi pariwisata. Sementara itu teknik Purposive Sampling untuk menentukan responden atas dasar tujuan penelitian dan pertimbangan peneliti, dimana mereka yang dIjadikan responden merupakan orang - orang yang dianggap memiliki informasi dan pengetahuan terkait masalah yang sedang ditelit.

\section{Variabel Penelitian}

Variabel dalam penelitian ini adalah pengembangan pariwisata sebagai upaya utuk mewujudkan keterpaduan dalam penggunaan berbagai sumberdaya pariwisata dan mengintegrasikan aspek diluar pariwisata dengan melihat indikator 3A (Atraksi, Aksesibilitas, Amenitas).

\section{Teknik Pengumpulan Data}

Teknik pengumpulan Data dalam penelitian ini adalah Survey Lapangan. Peneliti melakukan persiapan dan pengambilan data awal melalui

1. Survey

Untuk mengetahui terlebih dahulu Faktor Strategi eksternal (EFAS) yang meliputi peluang dan ancaman yang dapat diperoleh dari ligkungan luar kawasan pariwisata Selat Lembeh serta Faktor Strategy Internal (IFAS) yang terdiri atas kekuatan dan kelemahan yang ada dari dalam kawasan Pariwisata pulau Lembeh.

2. Kuesioner

Setelah tersedianya Data EFAS (external factor strategic analysis summary) dan IFAS (internal factor strategic analysis summary) yang didapat melalui proses survey, selanjutnya dibuatkan kuesioner atau matriks faktor strategi eksternal (peluang dan ancaman) serta faktor strategi internal (kekuatan dan kelemahan) dalam bentuk Tabel dengan memberi bobot, ratting dan skor pada masing - masing faktor strategi kuesioner yang dimaksud, yaitu melalui teknik pengumpulan data yang dilakukan dengan cara memberi beberapa rangkaian pertanyaan kepada responden untuk dijawab.

3. Studi dokumen

Penelitian ini juga melakukan studi dokumen penelitian terhadap semua dokumen yang terkait dengan penelitian ini seperti dokumen dokumen tertulis, baik berupa arsip-arsip, bukubuku yang relevan yang memberikan pendapat atau masukan, teori terkait, jurnal-jurnal, surat kabar, media online, majalah serta sumbersumber lainnya yang dapat dipertanggung jawabkan isinya yang dapat menunjang penelitian ini.

4. Wawancara

Wawancara merupakan teknik pengumpul-an data yang dilakukan dengan mengadakan komunikasi kepada informan pada objek penelitian. Wawancara dilakukan secara mendalam untuk menggali informasi dari informan atau orang yang dianggap mengetahui tentang permasalahan yang sedang dibahas penelitian.

5. Dokumentasi

Teknik dokumentasi dilakukan dengan cara mengumpulkan data-data tertulis yang sudah ada sebelumnya. Teknik pengambilan data secara tertulis bersumber pada catatan-catatan, arsip-arsip, gambar dan foto pada acara-acara tertentu yang ada dilokasi penelitian, yang berkaitan dengan penelitian dan bertujuan untuk memperjelas dan mendukung proses penelitian.

\section{Teknik Analisis Data}

Penelitian ini menggunakan analisis pengolahan data SWOT melalui proses analisis terhadap faktor Internal dan faktor Eksternal. Semua elemen dalam analisis SWOT didapatkan 
melalui jawaban atas pertanyaan yang diberikan kepada responden. Selanjutnya dilakukan penyusunan strategi sesuai analisis SWOT. Berikut ini adalah tahapan dalam penyusunan analisis SWOT:

a. Faktor Eksternal

Faktor eksternal adalah faktor daya tarik pariwisata yang meliputi peluang dan ancaman dalam menarik wisatawan ke kawasan Selat Lembeh. Analisis eksternal yang meliputi peluang dan ancaman dilakukan untuk mengetahui posisi pariwisata kawasan Selat Lembeh dalam lingkungan eksternalnya. Peluang bersifat positif atau menguntungkan sedangkan ancaman bersifat negatif atau tidak menguntungkan terhadap suatu lingkungan.

Adapun yang menjadi faktor eksternal pada pariwisata kawasan Selat Lembeh adalah:

1. Peluang (opportunity), yang menjadi faktor peluang dalam pengembangan pariwisata kawasan Selat Lembeh di Kota Bitung adalah:

(1) Tingginya minat wisatawan

(2) dibukanya penerbangan langsung China Manado pp,

(3) Tersedianya Teknologi Infomasi Komunikasi sebagai media promosi yang efektif dan efisien,

(4) Adanya dukungan pemerintah yang memprioritaskan pariwisata,

(5) Kebijakan Nasional yang menetapkan Kawasan Selat Lembeh sebagai Kawasan Strategi Pariwisata nasional (KSPN),

(6) Tingginya minat investasi bidang pariwisata.

2. Ancaman (Threat), yang menjadi faktor ancaman dalam pengembangan pariwisata kawasan Selat Lembeh di Kota Bitung adalah :

(1) Kebijakan pemerintah yang tumpang tindih terkait fungsi kawasan sebagai kawasan Industri (IHP) dan kawasan pariwisata.

(2) Kerusakan lingkungan,

(3) Bencana alam,

(4) Travel warning.

b. Faktor Internal

Faktor internal adalah faktor yang berasal dari dalam sistem pariwisata kawasan Selat Lembeh yang sifatnya sebagai Kekuatan (Strength) dan Kelemahan (Weakness). Faktor Internal pariwisata kawasan Selat Lembeh adalah:

1. Kekuatan (Strength), yang menjadi kekuatan pada pengembangan pariwisata kawasan Selat Lembeh adalah

(1) Keindahan daya tarik alam

(2) Keamanan wilayah

(3) Tersedianya prasarana transportasi

(4) Sikap sadar wisata masyarakat
(5) Peran serta pelaku uasaha dalam promosi.

2. Kelemahan (Weakness), yang menjadi kelemahan pada pengembangan pariwisata kawasan Selat Lembeh adalah:

(1) Daya tarik budaya masih kurang

(2) Fasilitas pariwisata masih kurang

(3) sarana transportasi masih kurang

(4) sistem transportasi masih kurang

(5) Kualitas SDM pelaku pariwisata masih kurang

(6) Fasilitas umum masih kurang.

Selanjutnya dibuatkan matriks sesuai tahapan dalam analisis SWOT yaitu matriks:

1. Matriks Faktor Strategi Eksternal

a. Setelah didapatkan faktor-faktor eksternal yang meliputi peluang dan ancaman selanjutnya dibuatkan Tabel matriks Faktor Strategi Internal dan faktor-faktor tersebut dimasukan pada kolom satu.

b. Beri bobot masing - masing faktor yang dimasukan dalam kolom dua. Jumlah seluruh bobot harus sebsar 1,00.

c. Hitung rating untuk masing - masing faktor dengan skala mulai dari 4 (sangat kuat) sampai 1 (sangat lemah) berdasarkan pengaruh faktor terhadap kondisi pengembangan pariwisata kawasan Selat Lembeh. Nilai Peluang bersifat positif dimana peluang semakin besar diberi nilai 4 jika peluangnya makin kecil diberi nilai 1. Ancaman bernilai negatif dimana semakin besar ancaman nilainya 1 sedangkan ancaman makin kecil diberi nilai 4.

d. Kalikan bobot pada kolom 2 dan rating pada kolom 3 untuk memperoleh skor masingmasing factor.

e. Jumlah skor (kolom 4) untuk memperoleh total skor. Nilai tital skor menunjukkan bagaimana lingkungan bereaksi terhadap faktor strategis eksternal.

2. Matriks Faktor Strategi Internal.

a. Setelah faktor -faktor strategis internal diidentifikasi, selanjutnya disusun faktor kekuatan dan kelemahan dalam Tabel Matriks faktor strategi internal dan dimasukan dalam kolom 1.

b. Beri bobot masing - masing faktor dengan nilai total tidak boleh melebihi 1,00.

c. Hitung rating untuk masing - masing faktor dengan skala mulai dari 4 (sangat kuat) sampai 1 (sangat lemah) berdasarkan pengaruh faktor terhadap kondisi pengembangan pariwisata kawasan Selat Lembeh. Nilai kekuatan bersifat positif dimana kekuatan semakin besar diberi nilai 4 jika kekuatan makin kecil diberi nilai 1 . 
kelemahan bernilai negatif dimana semakin besar ancaman nilainya 1 sedangkan kelemahan makin kecil diberi nilai 4.

d. Kalikan bobot pada kolom 2 dan rating pada kolom 3 untuk memperoleh skor masingmasing faktor.

e. Jumlah skor (kolom 4) untuk memperoleh total skor. Nilai total skor menunjukkan bagaimana lingkungan bereaksi terhadap faktor strategis iksternal. Nilai ini dapat digunakan untuk membandingkan suatu kondisi pariwisata dengan pariwisata lainnya.

3. Analisis Internal Eksternal

Matriks IE terdiri dari dua dimensi yaitu total skor dari IFE pada sumbu $\mathrm{X}$ dan total skor dari EFE pada sumbu Y. Pada sumbu X dari matriks IE, skor bobot IFE total 1,00 sampai 1,99 menunjukkan posisi internal yang lemah, skor 2,00 sampai 2,99 dianggap sedang, skor 3 sampai 4 adalah kuat. Serupa dengan pada sumbu Y Total skor EFE 1,00 sampai dengan 1,99 dipandang rendang, skor 2,00 sampai 2,99 dianggap sedang dan skor 3,00 hingga 4,00 adalah tinggi. Berdasarkan hasil perhitungan matriks IFE dan EFE dapat dilihat posisi pengembangan pariwisata kawasan Selat Lembeh saat ini. Matriks IE dapat dibagi menjadi tiga daerah utama yang memiliki implikasi strategi berbeda, yaitu:

1. Rekomendasi untuk divisi yang masuk dalam sel I, II, IV dapat digambarkan sebagai "tumbuh dan kembangkan". Strategi intensif (penetrasi pasar, pengembangan pasar, dan pengembangan produk) atau strategi integratif (integrasi ke belakang, ke depan, dan integrasi vertikal/horizontal) paling sesuai untuk divisi ini.

2. Divisi yang masuk sel III, V, VII dapat dikelola dengan cara terbaik dengan strategi “jaga dan pertahankan", penetrasi dasar dan pengembangan produk adalah dua strategi yang umum untuk tipe ini.

3. Rekomendasi yang umum diberikan untuk divisi yang masuk sel VI, VIII, dan IX adalah "tuai atau divestasi", organisasi yang mampu mencapai portofolio bisnis yang diposisikan dalam atau sekitar sel I dalam matriks IE.

4. Analisis SWOT

Untuk mendapatkan strategi yang tepat berdasarkan hasil matriks IFE dan EFE dilanjutkan dengan analisis SWOT untuk mengetahui posisi relatif dari pariwisata kawasan Selat Lembeh di Kota Bitung berada pada kuadran berapa. Perhitungan analisis SWOT sebagai berikut:

1. Jumlah perkalian IFAS yang meliputi faktor Kekuatan dan faktor kelemahan diselisihkan untuk mendaoatkan nilai titik Y

2. Jumlah perkalian faktor EFAS yang meliputi faktor Peluang dan faktor Ancaman diselisihkan untu mendapatkan nilai titik $X$.

Hasilnya dimasukkan dalam diagram posisi pengembangan pariwisata Kawasan Selat Lembeh di Kota Bitung. Dalam diagram ini tergambar posisi pariwisata kawasan Selat Lembeh berada pada kuadran ke berapa

\section{HASIL DAN PEMBAHASAN}

\section{Deskripsi Daerah Penelitian}

Secara geografi Kota Bitung terletak diantara 1023'23" - 1035'39" LU dan 125o1'43" 125o18'13" BT. Ini menunjukkan bahwa lokasi penelitian berada pada daerah yang beriklim tropis dengan dua tipe musim yaitu musim kemarau dan musim peghujan. Kota Bitung memiliki batas-batas wilayah secara administratif dengan kabupaten lain sebagai berikut:

- Sebelah Utara berbatasan dengan Kabupaten Minahasa Utara

- Sebelah Selatan berbatasan dengan lautan

- Sebelah Barat berbatasan dengan Kabupaten Minahasa Utara

- Sebelah Timur berbatasan dengan lautan.

Kawasan pariwisata Selat Lembeh merupakan kawasan yang terletak di Kota Bitung, Sulawesi Utara, Indonesia. Kawasan ini ini meliputi daerah perairan Selat Lembeh yang memisahkan daratan Pulau Sulawesi di Kota Bitung dengan pulau Lembeh yang mencakup Lima kecamatan yaitu kecamatan Aertembaga, Maesa dan kecamatan Madidir di wilayah daratan pulau Sulawesi, Kecamatan Lembeh Utara dan Kecamatan Lembeh Selatan diwilayah Pulau Lembeh Kota Bitung. Luas wilayah dan Jumlah penduduk per Kecamatan dapat dilihat pada Tabel 1 .

Tabel 1. Luas Wilayah dan Jumlah Penduduk Per Kecamatan.

\begin{tabular}{lrr}
\hline Kecamatan & Luas wilayah $($ Ha) & Jumlah penduduk (jiwa) \\
\hline Aertembaga & $3.309,80$ & 26.403 \\
Lembeh Utara & $2.766,00$ & 7.710 \\
Lembeh Selatan & $2.553,00$ & 8.963 \\
Madidir & $2.083,00$ & 34.253 \\
Girian & 516.55 & 30.537 \\
Matuari & $3.396,00$ & 43.253 \\
Ranowulu & $15.756,80$ & 19.776 \\
Maesa & 969,7 & 34.167 \\
\hline Total & $33.279,10$ & 205.167 \\
\hline Sumber data : Bitung Dalam angka 2016 &
\end{tabular}




\section{Potensi Pariwisata Kawasan Selat Lembeh}

Selat Lembeh yang merupakan bagian dari Kota Bitung yang memisahkan Pulau Lembeh dengan Daratan Kota Bitung memiliki panjang Selat $16 \mathrm{KM}$ dan lebar Selat 1,2 KM.

Potensi Pariwisata yang ada di Selat Lembeh meliputi:

1. Atraksi

a. Pariwisata Alam

Pariwisata alam adalah segala sesuatu yang berhubungan dengan wisata alam, termasuk pengusahaan objek dan daya tarik serta usaha yang terkait dengan wisata alam. Pariwisata alam di Kawasan Selat Lembeh dapat dilihat pada Tabel 2.

\begin{tabular}{cll} 
Tabel 2. & Objek Pariwisata Alam di Kawasan Selat Lembe \\
\hline No & Objek Wisata & Lokas Kelurahan \\
\hline 1 & Pantai pasir panjang & Pasir Panjang \\
2 & Pantai Kungkungan & Tandurusa \\
3 & Pantai Aer Prang & Makawidey \\
4 & Pantai Sandylangi & Pintu Kota \\
5 & Pantai Tokambahu & Makawidey \\
6 & Taman margasatwa & Tandurusa \\
7 & Kawasan Suaka Alam Batu Angus & Kasawari \\
8 & Sumber Air Panas Rumesung & Kasawari \\
9 & Keindahan bawah Laut dengan 93 Dive Spot & Sepanjang Selat \\
& & Lembeh \\
10 & Mangrove & Batu Kota \\
\hline Sumber : Dinas Pariwisata Kota Bitung 2018
\end{tabular}

b. Pariwisata Buatan

Pariwisata buatan adalah destinasi pariwisata yang memiliki daya tarik buatan manusia. Daya tarik buatan manusia adalah daya tarik wisata khusus yang merupakan kreasi artifisial (artificial crated) dan kegiatan -kegiatan manusia lainnya diluar ranah wisata alam dan wisata budaya. Pengembangan pariwisata buatan di kawasan Selat Lembeh Kota Bitung meliputi:

1. Monumen Trikora di Kelurahan Batu Lubang Lembeh Kecamatan Lembeh Selatan,

2. Patung Yesus Memberkati di Kelurahan Doorbolang,

3. Kampung wisata Pintu Kota Kecil di kelurahan Batu Kota,

4. Mercusuar di kawasan perairan suaka alam Batu Angus Tangkoko

c. Pariwisata Budaya

Pariwisata budaya adalah berbagai kegiatan pariwisata yang bertujuan berbagi dan menikmati wujud warisan sejarah dan budaya termasuk lanskap, bangunan-bangunan, koleksi benda sejarah, seni, identitas, tradisi dan bahasa. Kota Bitung dengan masyarakat yang heterogen menjadikan Kota Bitung sebagai titik pertemuan kebudayaan. Multi kuturalisme Bitung telah termanifestasi dalam berbagai unsur kebudayaan seperti kuliner, bahasa, seni budaya dan lain sebaginya.
Pariwisata budaya yang dapat dinikmati dikawasan Selat Lembeh adalah:

1. Ampat Wayer

2. Tari Tangkap Cakalang

3. Tari Soma Dampar,

4. Maengket,

5. Tari Katrili,

6. Tari kawasaran,

7. Calender of Even Pariwisata kota Bitung.

2. Aksesibilitas

Aksesibilitas dalam pariwisata berkenaan dengan kemudahan wisatawan untuk mencapai suatu objek pariwisata. Aksesibilitas sangat penting untuk diperhatikan mengingat aspek ini sangat berpengaruh besar bagi wisatawan baik terhadap kenyamanan, waktu dan biaya yang akan dikeluarkan. Destinasi pariwisata yang baik tidak lepas dari persyaratan aksesibiltas. Faktor - faktor yang mempengaruhi kualitas aksesibiltas pariwisata adalah kondisi jalan, jarak dan waktu tempuh, moda transportasi baik jumlah maupun kualitas, dan sistem transportasi yang meliputi informasi rute dan jadwal serta kemudahan reservasi.

Untuk aksesibilitas pariwisata kawasan pariwisata Selat Lembeh:

1. jarak tempuh dari bandara Sam Ratulangi kurang lebih $1.5 \mathrm{Jam}$, akses jalan yang baik dengan moda tranportasi darat yang tersedia

2. Jarak Tempuh dari pusat kota kurang lebih 15 menit sampai di titik penyeberangan dengan akses jalan yang baik dengan moda transportasi darat yang tersedia.

3. Akses jalan lingkar pulau Lembeh menuju destinasi pariwiata di pulau Lembeh

4. Akses jalan menuju destinasi pariwisata di daratan kota Bitung

5. Tersedianya moda transportasi darat dan laut yang disiapkan oleh pemerintah dalam bentuk kapal feri penyeberangan dan yang disiapkan oleh masyarakat/ pengusaha.

3. Amenitas

Amenitas adalah segala sesuatu yang mendukung pengembangan pariwisata yang bersifat meningkatkan kenyamanan wisatawan. Untuk kawasan Selat Lembeh amenitas yang tersedia adalah:

1. Prasarana umum yang ada di pulau Lembeh yaitu Air bersih, pengolahan limbah dan listrik belum memadai sistem telekomunikasi belum ada dan untuk kecamatan yang berada didaratan Kota Bitung sudah tersedia Listrik, telekomunikasi, pengolahan limbah. 
2. Fasilitas umum sudah tersedia yaitu sarana kesehatan yaitu puskesmas, pustu, sanitasi dan kebersihan, tempat ibadah, tempat parkir, tempat rekreasi, keamanan dan ketertiban.

3. Fasilitas pariwisata, tersedianya akomodasi, rumah makan/restoran, keimigrasian, papan informasi, toko cenderamata.

4. Standarisasi dan Sertifikasi usaha pariwisata.

\section{Pembangunan Pariwisata Kawasan Selat Lembeh}

Pembangunan suatu kawasan pariwisata merupakan tanggung jawab bersama semua pemangku kepentingan. Untuk Kota Bitung pembangunan pariwisatanya menggunakan pendekatan pembangunan yang berbasis pada pemberdayaan masyarakat (People oriented \& community based development), dimana nilai - nilai kerakyatan dan komunitas setempat sebagai sumberdaya utama serta dengan memperhitungkan nilai - nilai sosial budaya pembangunan (RIPARKOT Kota Bitung 2016). Oleh sebab itu setiap langkah perencanaan yang dibuat harus melibatkan masyarakat secara aktif. Hal ini dapat dilihat dalam proses perencanaan wilayah kota dalam setiap tahapan musyawarah perencanaan pembangunan kota Bitung serta dalam setiap konsultasi publik rencana pelaksanaan suatu usaha/kegiatan tetap melibatkan masyarakat karena masyarakat lokal adalah orang-orang yang paling tahu kondisi setempat, serta menjamin adanya komitmen masyarakat karena rasa memiliki yang kuat.

a. Peran Pemerintah

Pemerintah Kota Bitung telah berupaya untuk menggiatkan pembanguann pariwisata dikota Bitung termasuk di kawasan pariwisata Selat Lembeh. Sejalan dengan pemerintah pusat dan provinsi dengan menjadikan sektor pariwisata sebagai sektor unggulan disamping kesehatan dan pendidikan. berbagai program kegiatan yang dilakukan dengan tujuan untuk menggiatkan pariwisata seperti pelaksanaan Calender Of Events Pariwisata Kota Bitung, perbaikan sarana dan prasana pariwisata, menfasilitasi pembentukan Bitung Tourisme Board yang merupakan ajang pertemuan pemangku kepentingan pariwisata kota Bitung untuk membahas berbagai permasalahan pariwisata kota Bitung, dalam maupun diluar negeri, sosialisasi SADAR WISATA/SAPTA PESONA, melakukan promosi pariwisata baik secara langsung maupun tidak langsung ditiap kegiatan pemerintah baik di dalam maupun diluar negeri, menjaga stabilitas keamanan dan ketertiban bersama pihak kepolisian dan TNI, mengawasi dan melestarikan lingkungan, pengembangan UKM pariwisata, kemudahan investasi dan merangsang kreativitas serta menumbuh kembangkan berbagai atraksi seni budaya.

b. Peran Masyarakat

Masyarakat disekitar kawasan pariwisata dengan mata pencaharian yang beraneka ragam, didominasi dengan profesi nelayan karena sumber daya laut yang tersedia disamping bekerja disektor yang berkaitan dengan pariwisata. Resort-resort yang tersebar di kawasan Selat Lembeh banyak memanfaatkan tenaga kerja lokal, pemandu pariwisata, pengusaha cendramata dan pengelola tempat wisata adalah masyarakat lokal sehingga masyarakat memahami dan merasakan manfaat pariwisata secara ekonomi.

Masyarakat juga secara aktif menunjang pariwisata dengan menjaga lingkungan yang nyaman bagi kegiatan pariwisata di wilayahnya. Ketertiban keamanan yang terkendali serta kenyamanan lingkungan termasuk kebersihan merupakan peran serta masyarakat dalam menciptakan lingkungan yang nyaman bagi wisatawan.

c. Peran Swasta

Pihak swasta memiliki peran yang sangat besar dalam pembangunan pariwisata karena pemerintah tidak akan mampu membangun hanya dengan mengandalkan sumber daya yang ada pada pemerintah. Keterbatasan sumber daya keuangan dan sumber daya manusia pada pemerintah sehingga pemerintah membutuhkan dukungan dari pihak swasta. Pihak swasta juga berperan secara aktif dalam promosi pariwisata Selat Lembeh yang diikuti oleh pihak Resort/dive Resort baik ditingkat nasional maupun internasional dalam berbagai event pameran/expo secara mandiri tidak tergantung pada pembiayaan pemerintah.

Dalam pelaksanaan kegiatan yang dilakukan oleh pemerintah seperti pelaksanaan Calender Of Events pariwisata Kota Bitung pihak swasta juga secara aktiv berpartisipasi baik mendukung dengan ikut serta memeriahkan acara, membantu mempromosikan serta mensupport kekuranggan anggaran yang tidak dapat dibiayai dalam APBD kota Bitung melalui CSR (coorporate sosial Responsibility) perusahan maupun bantuan sukarela. Disamping itu pihak swasta juga secara aktif ikut dalam 
upaya menjaga dan melestarikan lingkungan dengan terlibat pada kegiatan-kegiatan turun langsung dilapangan untuk pembersihan kawasan Selat Lembeh.

\section{Karekteristik Responden}

Responden penelitian berjumlah 20 orang dan memiliki karakteristik yang berbeda sehingga perlu dijelaskan melalui beberapa kategori yaitu pendidikan, jenis kelamin, umur dan pekerjaan.

\section{Jenis Kelamin}

Tabel 3 menunjukkan bahwa jenis kelamin responden laki-laki sebanyak 8 orang (40\%) dan responden perempuan sebanyak 12 orang $(60 \%)$ dari keseluruhan jumlah informan.

Tabel 3. Jenis Kelamin Responden

\begin{tabular}{cccr}
\hline No & Jenis Kelamin & Frekuensi & Persentase (\%) \\
\hline 1 & Laki - Laki & 8 & 40 \\
2 & Perempuan & 12 & 60 \\
\hline \multicolumn{2}{l}{ Sumber : Hasil Analisis Data 2018 } & Total & 100 \\
\hline
\end{tabular}

\section{Usia}

Tabel 4 menunjukkan bahwa usia responden antara 21 sampai 30 tahun sebanyak 4 orang atau 20 $\%$ dan usia 31 sampai dengan 40 tahun sebanyak 7 orang atau $35 \%$ serta responden yang berusia 41 sampai dengan 50 tahun sebanyak 5 orang atau $25 \%$ serta responden yang berusia 51 sampai dengan 60 tahun sebanyak 4 orang atau $20 \%$, sedangkan usia 0 sampai dengan 21 tahun, dan usia 61 tahun sampai dengan 70 tahun tidak ada.

\section{Tabel 4. Usia Responden}

\begin{tabular}{cccr}
\hline No & Usia & $\begin{array}{r}\text { Frekuens } \\
\mathbf{i}\end{array}$ & $\begin{array}{r}\text { Persentase } \\
(\boldsymbol{\%})\end{array}$ \\
\hline 1 & $0-10$ & - & - \\
2 & $11-20$ & - & - \\
3 & $21-30$ & 4 & 20.00 \\
4 & $31-40$ & 7 & 35.00 \\
5 & $41-50$ & 5 & 25.00 \\
6 & $51-60$ & 4 & 20.00 \\
7 & $61-70$ & - & - \\
\hline \multicolumn{4}{l}{ Total } \\
\multicolumn{4}{l}{ Sumber: Hasil Analisis data 2018 }
\end{tabular}

\section{Pendidikan}

Tabel 5 menunjukkan bahwa jumlah responden yang berpendidikan SLTA seebanyak 4 orang atau 20\%, Diploma sebanyak 6 orang atau $30 \%$, Strata satu/S1 sebanyak 7 Orang atau $35 \%$ serta Strata Dua /S2 sebanyak 3 orang atau $15 \%$ sedangkan untuk pendidikan Belum Tamat SD, Sekolah Lanjutan Tingkat Pertama/SLTP, dan Strata Tiga/S3 tidak ada dari keseluruhan informan.
Tabel 5. Pendidikan Responden

\begin{tabular}{clcr}
\hline No & Pendidikan & Frekuensi & Persentase (\%) \\
\hline 1 & Belum Tamat SD & - & - \\
2 & SD & - & - \\
3 & SLTP & - & - \\
4 & SLTA & 4 & 20 \\
5 & Diploma & 6 & 30 \\
6 & S1 & 7 & 35 \\
7 & S2 & 3 & 15 \\
8 & S3 & - & - \\
\hline \multicolumn{4}{l}{ Total } \\
\hline Sumber : Hasil analisis Data 2018
\end{tabular}

Tabel 5 menunjukkan bahwa jumlah responden yang berpendidikan SLTA seebanyak 4 orang atau $20 \%$, Diploma sebanyak 6 orang atau $30 \%$, Strata satu/S1 sebanyak 7 Orang atau $35 \%$ serta Strata Dua /S2 sebanyak 3 orang atau $15 \%$ sedangkan untuk pendidikan Belum Tamat SD, Sekolah Lanjutan Tingkat Pertama/SLTP, dan Strata Tiga/S3 tidak ada dari keseluruhan informan.

\section{Pekerjaan}

Tabel 6 menunjukkan bahwa status pekerjaan responden yang bekerja sebagai Pegawai negeri Sipil/PNS sebanyak 5 orang atau $25 \%$, Swasta 10 orang atau $50 \%$ dan pengusaha 5 orang atau $25 \%$, sedangkan responden dengan status pekerjaan sebagai honorer, petani, nelayan dan peternak tidak ada dari keseluruhan jumlah responden yang ada.

Tabel 6. Data Pekerjaan Responden

\begin{tabular}{llcc}
\hline No & \multicolumn{1}{c}{ Pekerjaan } & Frekuensi & Persentase (\%) \\
\hline 1 & P N S & 5 & 25 \\
2 & Honorer & - & - \\
3 & Swasta & 10 & 50 \\
4 & Pengusaha & 5 & 25 \\
5 & Petani & - & - \\
6 & Nelayan & - & - \\
7 & Peternak & - & - \\
\hline & & 20 & 100 \\
\hline
\end{tabular}

\section{Analisis SWOT}

Analisis SWOT adalah analisis untuk mendapatkan strategi terbaik dengan memaksimalkan kekuatan (strength) dan peluang (oppotunities), dan secara bersamaan mengurangi kelemahan (weakness) dan mengantisipasi ancaman (Treath). berikut ini akan diuraikan analisis SWOT terhadap faktor -faktor strategis yang ada dalam upaya mengembangkan pariwisata di Kawasan Selat Lembeh Kota Bitung. Analisis yang akan dilakukan meliputi faktor Internal dan faktor eksternal sebagai berikut:

\section{Faktor-faktor Strategis}

Faktor -faktor strategis yang ada dalam upaya mengembangkan pariwisata di Kawasan Selat Lembeh Kota Bitung antara lain faktor Strategis Internal (IFAS), dan Faktor Strategis Eksternal (EFAS). 


\section{Faktor Strategis Internal (IFAS)}

Analisis lingkungan internal yang dilakukan yaitu terhadap faktor -faktor strategis internal yang terdiri dari kekuatan dan kelemahan dalam pengembangan pariwisata kawasan Selat Lembeh di Kota Bitung. Adapun faktor - faktor strategis internal tersebut antara lain:

a. Faktor Kekuatan:

1. Daya Tarik alam, yang dimaksud dengan daya tarik alam sebagai kekuatan internal dari kawasan pariwisata Selat Lembeh adalah keindahan alamnya baik pantainya, laut terlebih keindahan dan keunikan bawah lautnya.

2. Keamanan wilayah adanya jaminan kenyamanan dan keselamatan bagi wisatawan.

3. Daya tarik buatan yang menjadi kekuatan kawasan pariwisata Selat Lembeh adalah adanya beberapa destinasi buatan seperti Patung Yesus memberkati, Monumen Trikora, dan Mercusuar Batuangus.

4. Prasarana transportasi, dalam hal ini tersedianya dermaga pariwisata.

5. Sikap Sadar masyarakat yang menunjang pariwisata.

6. Peran serta pelaku usaha pariwisata merupakan sebuah kekuatan yang sangat membantu pemerintah, dimana pelaku usaha pariwisata secara mandiri melakukan promosi pariwisata Kasawasan Selat Lembeh diberbagai pameran/expo di dalam maupun luar negeri. Hal ini merupakan sebuah kekuatan yang sangat membantu pemerintah yang sangat terbatas ketersediaan dana untuk kegiatan promosi.

b. Faktor Kelemahan:

1. Daya tarik budaya masih kurang, belum dikemas dan digarap secara maksimal untuk bisa menjadi salah satu magnet untuk mendatangkan wisatawan.

2. Fasilitas pariwisata, meliputi ketersediaan restoran, Tourism Inforation Center, papan penunjuk arah, shouvenirshop dll masih kurang memadai.

3. Sarana transportasi, ketersedian jumlah dan kualitas feri penyeberangan yang belum memenuhi kebutuhan terlebih pada saat-saat tertentu yang mengalami lonjakan pengunjung/wisatawan merupa-kan sebuah kelemahan.

4. Sistem transportasi yang menjadi kelemahan adalah jadwal pelayaran dimana saat ini untuk moda transportasi penyeberangan yang memadai yang tersedia baru satu unit dengan jadwal yang masih belum memenuhi kebutuhan.

5. Standarisasi dan sertifikasi usaha, kurangnya pelaku usaha yang memiliki standarisasi/certificate yang sesuai.

6. fasilitas umum, masih kurang tersedianya dan kurang memadainya fasilitas umum yang ada, seperti ketersediaan toilet dan air bersih, rest room dan sarana kesehatan.

Setelah melakukan analisis kondisi lingkungan internal, selanjutnya dilakukan penghitungan bobot dan rating internal untuk mengetahui letak strategis Pariwisata Kawasan Selat Lembeh di Kota Bitung yang dianggap perlu untuk dilakukan pengembangan. Penghitungan bobot faktor - aktor tersebut dilakukan dengan meembuat tabulasi data Skor IFAS (Internal Strategic Factor Analysis Summery) dapat dilihat pada lampiran. Penghitungan bobot dengan ketentuan bobot 0,00 tidak penting sampai 1,00 sangat penting.

Faktor Strategis Eksternal (EFAS)

Analisis Faktor - faktor strategis yang berasal dari luar atau faktor Eksternal meliputi faktor Peluang dan Ancaman. Faktor strategis eksternal yang akan dianalisis pada pariwisata kawasan Selat Lembeh meliputi

a. Peluang:

1. Tingginya minat wisatawan.

2. Dibukanya penerbangan langsung China Manado pp.

3. Tehnologi Informasi komunikasi sebagai media promosi yang efektif dan efisien.

4. Dukungan pemerintah terhadap pariwisata sebagai program prioritas.

5. Kebijakan pemerintah dalam hal ini kementerian Pariwisata dalam rencana induk Pengembangan Pariwisata Indonesia (RIPARNAS) menetapkan Kawasan Selat Lembeh sebagai salah satu dari 80 Kawasaki Strategi Pengembangan Pariwisata Nasional (KSPN). Hal ini sangat menguntungkan Kawasan Selat Lembeh karena dengan demikian akan mendapat perhatian lebih dari kementerian Pariwisata baik dari segi promosi, kegiatan maupun pendanaan.

6. Kebijakan pemerintah Kota Bitung untuk menggiatkan investasi di wilayahnya dengan salah satu strategi kemudahan investasi melalui perijinan satu pintu merupakan peluang yang merangsang datangnya investor bukan hanya untuk industri tapi juga investor bidang pariwisata. 
b. Ancaman:

1. Kebijakan Pemerintah yang tumpang tindih adalah kebijakan pemerintah antar sektor yang tidak sejalan seperti penetapan kawasan Selat Lembeh sebagai kawasan pengembangan pariwisata dan sebagai kawasan industri dengan menetapkan Pelabuhan Bitung sebagai Internasional hub port dan wilayah Kawasan Ekonomi Khusus (KEK). Dengan direncanakannya pelabuhan Bitung menjadi Internasional Hub Port dan sebgai kawasan industri maka hal ini akan sangat berpengaruh terhadap kelestarian lingkungan Kawasan Selat Lembeh mengingat sifat industri yang rentan merusak lingkungan sementara pariwiata kawasan Selat Lembeh mengandalkan keindahan bawah laut dan lingkungan.

2. Kerusakan lingkungan, merupakan ancaman seperti halnya akibat ancaman kegiatan industri, tetapi disebabkan oleh karena kelalaian manusia seperti produksi sampah plastik yang mencemari laut tempat kegiatan penyelaman serta kerusakan habitat tempat mahluk hidup air yang unik di Selat Lembeh hidup.

3. Rentan terhadap bencana alam, keadaan topografi kawasan pariwisata daratan sekitar Selat Lembeh yang rentan terhadap bencana alam. Bencana alam yang sudah oernah terjadi beberapa kali merusak infrastruktur akses jalan menuju lokasi destinasi pariwisata.

4. Travel warning.

\section{Analisis Faktor - Faktor Strategis}

Analisis faktor-faktor strategis yang ada dalam upaya mengembangkan pariwisata di Kawasan Selat Lembeh Kota Bitung antara lain analisis faktor Strategis Internal (IFAS), dan analisis faktor Strategis Eksternal (EFAS).

\section{Analisis Faktor IFAS (Internal Factor Strategic Analysis Summary)}

Setelah selesai identifikasi faktor - faktor strategis selanjutnya dilakukan pembobotan dan rating pada faktor - faktor strategis yang bertujuan untuk mengklasifikasi faktor - faktor strategis baik internal maupun eksternal. Hasil pemberian bobot dan rating terhadap faktor internal IFAS tersebut akan menunjukkan apakah faktor tersebut merupakan kekuatan yang besar atau kecil serta kelemahan besar atau kecil. Bobot menunjukkan prioritas kepentingan faktor - faktor tersebut bagi pengembangan pariwisata kawasan Selat Lembeh kota Bitung. Perhitungan bobot faktor internal IFAS tersebut dilakukan dengan membuat tabulasi data skor IFAS dilihat pada Tabel 7.
Tabel 7. Matriks IFAS Pengembangan Pariwisata Kawasan Selat

\begin{tabular}{|c|c|c|c|c|}
\hline No & FAKTOR STRATEGIS & Bobot & Rating & Skor \\
\hline & IFAS KEKUATAN & & & \\
\hline 1 & Daya tarik alam & 0.120 & 4.15 & 0.498 \\
\hline 2 & Keamanan wilayah & 0.105 & 3.65 & 0.384 \\
\hline 3 & Daya tarik buatan & 0.104 & 3.00 & 0.312 \\
\hline 4 & $\begin{array}{l}\text { Tersedianya prasarana } \\
\text { transportasi }\end{array}$ & 0.092 & 3.10 & 0.286 \\
\hline 5 & Sikap Masyarakat & 0.099 & 3.95 & 0.391 \\
\hline \multirow[t]{3}{*}{6} & $\begin{array}{l}\text { Peran pelaku usaha dalam } \\
\text { promosi }\end{array}$ & 0.114 & 3.80 & 0.434 \\
\hline & & Sub Total & & 2.305 \\
\hline & IFAS KELEMAHAN & & & \\
\hline 1 & $\begin{array}{l}\text { Daya tarik budaya masih } \\
\text { kurang }\end{array}$ & 0.063 & 2.20 & 0.139 \\
\hline 2 & $\begin{array}{l}\text { Fasilitas pariwisata kurang } \\
\text { memadai }\end{array}$ & 0.066 & 2.50 & 0.165 \\
\hline 3 & Fasilitas umum masih kurang & 0.065 & 2.10 & 0.137 \\
\hline 4 & $\begin{array}{l}\text { Sistem transportasi kurang } \\
\text { memadai }\end{array}$ & 0.059 & 1.75 & 0.104 \\
\hline 5 & $\begin{array}{l}\text { Kualitas SDM pelaku } \\
\text { pariwisata masih kurang }\end{array}$ & 0.061 & 1.80 & 0.110 \\
\hline \multirow[t]{3}{*}{6} & $\begin{array}{l}\text { Sarana transportasi masih } \\
\text { kurang }\end{array}$ & 0.055 & 2.10 & 0.116 \\
\hline & & Sub Total & & 0.771 \\
\hline & Total & 1.000 & & 3.076 \\
\hline
\end{tabular}

Tabel 7 menunjukkan hasil perhitungan analisis diperoleh total skor untuk faktor Internal yang meliputi kekuatan dan kelemahan adalah 3 . 076 yang menunjukkan bahwa pariwisata kawasan Selat Lembeh berada pada posisi kuat dalam memanfaatkan kekuatan untuk mengatasi kelemahan yang dihadapi dalam pengembangan pariwisata kawasan Selat Lembeh di Kota Bitung. Hal ini menunjukkan bahwa dengan berbagai kekuatan yang ada pengembangan pariwisata kawasan Selat Lembeh mampu mengimbangi berbagai kelemahan yang ada dengan memanfaatkan berbagai kekuatan yang dimiliki, hal ini dilihat dari skor hasil analisis berada pada posisi 3.076 atau berada diatas 3.00. Faktor yang merupakan kekuatan terbesar dalam strategi pengembangan pariwisata Kawasan Selat Lembeh adalah kekuatan daya tarik alam yaitu sebesar 0.498. Hal ini menunjukkan bahwa daya tarik alam dalam hal ini keindahan dan keunikan alam khususnya bawah laut kawasan Selat Lembeh adalah pesona utama yang menjadi daya tarik wisatawan untuk berkunjung di kawasan Selat Lembeh. Keunikan bawah laut Selat Lembeh sudah terkenal di Indonesia maupun manca negara sebagai surga "Muck Diving" yang menantang wisatawan untuk menikmatinya melalui kegiatan pariwisata air laut baik untuk diving maupun untuk menikmati keindahan landscapenya.

Sedangkan untuk kelemahan utama yang dimiliki Pariwisata Kawasan Selat Lembeh adalah fasilitas umum yang masih kurang 0.104. Hal ini dapat dilihat di lokasi - lokasi yang menjadi objek wisata dimana fasilitas umum yang ada masih sangat kurang bahkan sangat tidak memadai. Ketersedian sarana sanitasi seperti rest area yang masih kurang memadai bahkan dibeberapa lokasi destinasi 
pariwisata belum ada, ketersediaan air bersih yang belum memadai, tempat/ruang ganti yang tidak tersedia, tidak adanya fasilitas kesehatan/ rumah sakit dengan fasilitas hyperbaric yang memadai mengingat kegiatan utama pariwisata kawasan Selat Lembeh adalah Diving.

Fasilitas umum yang kurang merupakan ancaman yang sangat besar karena hal ini menyangkut kenyamanan bagi wisatawan yang berkunjung, sehigga dapat berpengaruh terhadap minat kunjungan wisatawan. Kenyamanan yang diberikan menimbulkan kesan bagi wisatawan yang selanjutnya dapat menjadi alasan mereka untuk kembali berkunjung atau menjadi promosi bagi wisatawan lainnya untuk berkunjung di kawasan Pariwisata Selat Lembeh dan akan terjadi sebaliknya jika kesan yang mereka dapatkan adalah kurang baik.

\section{Analisis Faktor EFAS (Eksternal Factor Strategic Analysis Summary)}

Analisis kondisi Eksternal dilakukan terhadap faktor -faktor strategis yang terdiri atas Peluang dan ancaman dalam oengembangan pariwisata Kawasan Selat Lembeh di Kota Biung. Hasil analisis dapat dilihat pada Tabel 8 Sesuai hasil analisis faktor strategis eksternal terhadap faktor strategis peluang dan ancaman yang dilakukan diatas maka skor total yang didapat adalah 3.396 . hal ini menunjukkan bahwa Pariwisata Kawasan Selat Lembeh di Kota Bitung berada pada posisi eksternal yang kuat. ini berarti Pengembangan pariwisata kawasan Selat Lembeh di Kota Bitung mampu memanfaatkan setiap peluang dan mengatasi setiap ancaman yang ada karena berada pada posisi diatas (3.00).

Tabel 8. Matrik EFAS Pengembangan Pariwisata Kawasan Selat Lembeh

\begin{tabular}{|c|c|c|c|c|}
\hline No & FAKTOR STRATEGIS & Bobot & Rating & Skor \\
\hline & EFAS PELUANG & & & \\
\hline 1 & Tingginya minat wisatawan & 0.141 & 4.35 & 0.614 \\
\hline 2 & $\begin{array}{l}\text { Dibukanya Penerbangan China } \\
\text { - Manado }\end{array}$ & 0.113 & 3.40 & 0.385 \\
\hline 3 & $\begin{array}{l}\text { TIC sebagai media promosi } \\
\text { yang efektif dan efisien }\end{array}$ & 0.136 & 4.20 & 0.572 \\
\hline 4 & $\begin{array}{l}\text { Dukungan Pemerintah } \\
\text { Terhadap pariwisata unggulan }\end{array}$ & 0.098 & 3.35 & 0.329 \\
\hline 5 & $\begin{array}{l}\text { Kebijakan nasional sebagai } \\
\text { KSPN }\end{array}$ & 0.105 & 3.70 & 0.389 \\
\hline 6 & Tingginya Minat Investasi & 0.116 & 3.90 & 0.453 \\
\hline & & \multicolumn{2}{|c|}{ Sub Total } & 2.754 \\
\hline & \multicolumn{4}{|l|}{ EFAS ANCAMAN } \\
\hline 1 & $\begin{array}{l}\text { Kebijakan pemerintah yang } \\
\text { tumpang tindih }\end{array}$ & 0.074 & 2.30 & 0.171 \\
\hline 2 & Travel Warning & 0.067 & 2.30 & 0.155 \\
\hline 3 & Rentan terhadap bencana alam & 0.080 & 2.10 & 0.168 \\
\hline 4 & Kerusakan Lingkungan & 0.074 & 2.00 & 0.148 \\
\hline & & \multicolumn{2}{|c|}{ Sub Total } & 0.642 \\
\hline & Total & 1.000 & & 3.396 \\
\hline
\end{tabular}

Sumber : Hasil analisis data 2018
Tabel 8 menunjukkan bahwa pengembangan pariwisata kawasan Selat Lembeh di Kota Bitung merespon dengan sangat baik terhadap setiap peluang yang ada dan mampu mengatasi setiap ancaman, sehingga dapat meminimalkan ancaman yang mungkin timbul. Faktor peluang yang terbesar dalam pengembangan pariwisata kawasan Selat Lembeh di Kota Bitung terdapat pada faktor tingginya minat wisatawan untuk diving dengan skor 0.614. dimana faktor ini menjadi peluang untuk mengembangkan pariwisata kawasan Selat Lembeh di kota Bitung, dimana tingginya minat wisatawan berarti berpengaruh terhadap jumlah kunjungan wisatawan yang pada akhirnya menggerakkan sektor lain yang terkait dengan pariwisata.

Adapun ancaman terbesar yang ada pada pengembangan pariwisata Kawasan Selat Lembeh di Kota Bitung adalah faktor kerusakan lingkungan dengan skor 0.148. Pariwisata Kawasan Selat Lembeh yang kekuatan internalnya adalah daya tarik alamnya lebih khusus keindahan bawah lautnya mengalami ancaman kerusakan lingkungan yang sifatnya eksternal atau dari luar. Potensi kerusakan lingkungan berasal dari luar seperti kerusakan habitat mahluk hidup akibat penumpukan sampah plastik yang dibuang oleh kapal - kapal dan limbah rumah tangga dari daerah lain maupun dari Kota Bitung sendiri, ulah manusia - manusia yang tidak bertanggung jawab dalam mengeksploitasi hasil laut seperti yang merusak terumbu karang serta kegiatan industri akibat kebijakan tata ruang wilayah yang kurang tegas. Walaupun demikian berbagai upaya telah dilakukan oleh pemerintah untuk mencegah kerusakan lingkungan seperti sosialisasi pelestarian lingkungan serta gerakan bersih - bersih pantai yang dilakukan bekerjasama dengan pihak TNI dan swasta.

\section{Analisis Internal - Eksternal (IE)}

Hasil analisis strategi faktor Internal dan faktor Eksternal dimasukkan dalam matriks Internal Eksternal sebagai tahap pencocokan strategi pengembangan Pariwisata Kawasan Selat Lembeh di Kota Bitung. Didapatkan nilai Skor total IFAS (Internal Factor Strategic Analysis Summary) adalah 3.076 dan EFAS (External Factor Strategic Analysis Summary) adalah 3.396. Hasil skor total matriks IFAS berada pada sumbu $X$ dan skor total matriks EFAS berada pada sumbu Y. Posisi Pengembangan Pariwisata Kawasan Selat Lembeh di Kota Bitung dilihat pada Tabel 9.

Agrisosioekonomi: 
Tabel 9. Matriks IE Pengembanagan Pariwisata Kawasan Selat Lembeh

\begin{tabular}{|c|c|c|c|}
\hline \multicolumn{4}{|c|}{ SKOR BOBOT } \\
\hline $\begin{array}{ll}\text { E } & \text { IFAS } \\
F & \end{array}$ & Kuat & Sedang & Lemah \\
\hline A & & & \\
\hline S & 3 & 2 & 1 \\
\hline $\begin{array}{l}\text { Tinggi } \\
3.00-4.00\end{array}$ & I & II & III \\
\hline $\begin{array}{l}\text { Sedang } \\
2.00-2.99\end{array}$ & IV & $\mathrm{V}$ & VI \\
\hline $\begin{array}{l}\text { Rendah } \\
1.00-1.99 \\
1\end{array}$ & VII & VIII & IX \\
\hline
\end{tabular}

Sumber: Hasil Analisis Data IE, 2018

Tabel 9 menunjukkan bahwa skor pembobotan total pada matriks internal eksternal (IE) yang dapat dilihat pada Tabel 9 menggambarkan bahwa posisi pengembangan pariwisata Kawasan Selat Lembeh berada pada sel I atau berada pada posisi strategi melalui integrasi Vertikal yang dapat digambarkan sebagai "tumbuh dan berkembang". Hal ini merupakan strategi utama untuk mengembangkan pariwisata kawasan Selat Lembeh dengan cara membangun dan memperluas potensi pariwisata serta faktor -faktor pendukung terkait lainnya yang ada guna meningkatkan daya tarik yang pada akhirnya dapat meningkatkan kunjungan wisatawan.

\section{Analisis SWOT}

Dari perhitungan nilai faktor strategis IFAS (Internal Factor Strategic Analysis Summary) diperoleh hasil dengan total IFAS sebesar 3,076 dan EFAS (Eksternal Factor Stategic Analysis Summary) sebesar 3.396. Selanjutnya dapatlah dilanjutkan dengan analisis SWOT untuk mengetahui posisi relatif Pariwisata Kawasan Selat Lembeh di Kota Bitung yang ber ada pada kuadran ke berapa, I, II, III atau IV. Perhitungan analisis SWOT adalah sebagai berikut:

a. Jumlah dari perkalian faktor strategis IFAS yang meliputi faktor Kekuatan (Strength) dan Kelemahan (weakness) diselisihkan untuk mendapatkan nilai titik $X$. Dimana perhitunganya adalah sebagai berikut:

Kekuatan (strength) $\quad: 2.305$

Kelemahan (weakness) : 0.771

Titik X : Strength - Weakness $=1.534$

b. Jumlah perkalian faktor strategis EFAS yang meliputi faktor Peluang (Opportunity) dan Ancaman (Threat) diselisihkan untuk mendapatkan nilai titik Y.

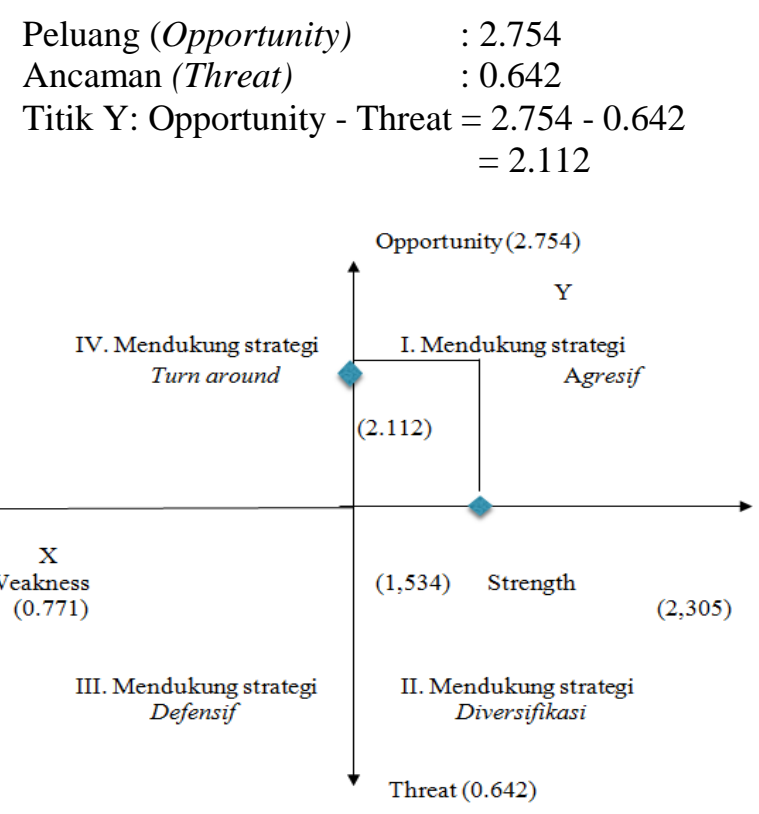

Gambar 1. Diagram Posisi Pengembangan Pariwisata Kawasan selat Lembeh di Kota Bitung

Gambar 1 menunjukkan strategi pengembangan pariwisata kawasan Selat Lembeh di Kota Bitung terletak pada posisi kuadran I atau terletak antara Peluang (opportunity) pada faktor Eksternal dan Kekuatan (strength) pada faktor Internal. Hal ini menunjukkan posisi pengembangan pariwisata kawasan Selat Lembeh di kota Bitung berada pada strategi pengembangan (kuadran I) yaitu strategi yang didesain untuk mencapai pertumbuhan jumlah kunjungan wisatawan baik dalam jumlah, frekwensi maupun lama tinggal wisatawan dengan meningkatan kualitas faktor faktor terkait pembangunan pariwisata ( atraksi, aksesibilitas dan amenitas). Posisi kuadran I tersebut menunjukkan posisi yang sangat menguntungkan karena pariwisata kawasan Selat Lembeh di Kota Bitung memiliki peluang dan kekuatan yang tinggi yang dapat dimanfaatkan dalam pengembangan pariwisata yang lebih baik lagi. Strategi yang dapat diterapkan dalam kondisi seperti ini adalah strategi yang mendukung kebijakan pertumbuhan.

\section{Strategi Pengembangan Pariwisata Kawasan Selat Lembeh}

Selanjutnya matriks strategi - strategi yang dapat dilakukan untuk pengembangan Pariwisata Kawasan Selat Lembeh di Kota Bitung. Strategi strategi tersebut dimasukan dalam matriks Analisis SWOT. Matriks ini dapat menggambarkan secara jelas bagaimana peluang dan ancaman yang dihadapi dapat disesuaikan dengan kekuatan dan kelemahan yang dimiliki. Matriks analisis SWOT selanjutnya disajikan pada Tabel 10. 
Tabel 10. Matriks SWOT Pengembanagan Pariwisata Kawasan Selat Lembeh

\begin{tabular}{|c|c|c|}
\hline Identifikasi Faktor & Kekuatan (Strength) & Kelemahan (Weakness) \\
\hline $\begin{array}{l}\text { E } \\
\text { F } \\
\text { A } \\
\text { S }\end{array}$ & $\begin{array}{l}\text { 1. Daya tarik alam } \\
\text { 2. Keamanan wilayah } \\
\text { 3. Daya tarik buatan } \\
\text { 4. Tersedianya prasarana } \\
\text { transportasi } \\
\text { 5. Sikap sadar wisata } \\
\text { masyarakat } \\
\text { 6. Peran serta pelaku usaha dalam } \\
\text { promosi }\end{array}$ & $\begin{array}{l}\text { 1. Tarik budaya masih kurang } \\
\text { 2. Fasilitas pariwisata kurang } \\
\text { memadai } \\
\text { 3. Sarana transportasi masih } \\
\text { kurang } \\
\text { 4. System transportasi yang } \\
\text { masih kurang } \\
\text { 5. Kualitas SDM pelaku } \\
\text { pariwisata masih kurang } \\
\text { 6. Fasilitas umum masih kurang } \\
\text { memadai }\end{array}$ \\
\hline Peluang (opportunity) & Strategi SO & Strategi WO \\
\hline $\begin{array}{l}\text { 1. Tingginya minat wisatawan } \\
\text { 2. Dibukanya penerbangan } \\
\text { langsung China - Manado } \\
\text { 3. TIC sebagai sebagai media } \\
\text { promosi efektif dan efisien } \\
\text { 4. Dukungan pemerintah ter- } \\
\text { hadap pariwisata unggulan } \\
\text { 5. Kebijakan nasional sebagai } \\
\text { KSPN } \\
\text { 6. Tingginya minat investasi }\end{array}$ & 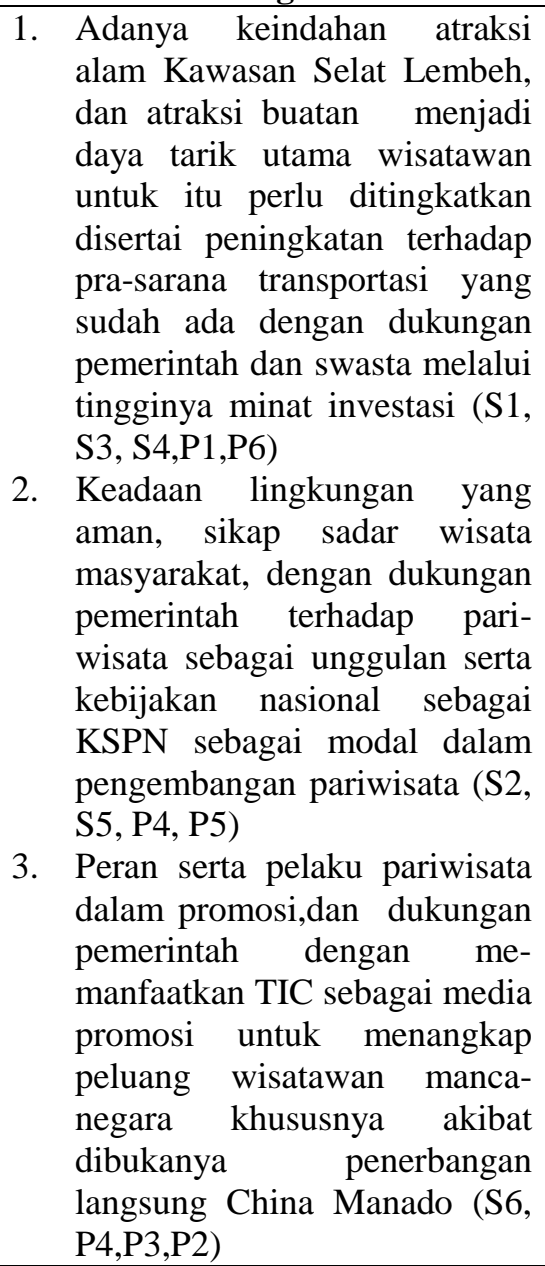 & $\begin{array}{l}\text { 1. Tingginya minat wisatawan } \\
\text { harus ditunjang dengan } \\
\text { berbagai fasilitas pendukung } \\
\text { seperti fasilitas pariwisata } \\
\text { dan umum, sarana dan sistem } \\
\text { transportasi, yanglebih baik } \\
\text { dan memadai, serta pening- } \\
\text { katan kualitas SDM sehingga } \\
\text { perlu dilakukan perbaikan } \\
\text { dengan memanfaatkan duku- } \\
\text { ngan dari pemerintah dimana } \\
\text { pariwisata sebagai unggulan } \\
\text { dan KSPN serta peluang } \\
\text { tingginya minat investasi } \\
\text { (W2,W3, W4, W5, W6, P1, } \\
\text { P4, P5,P6) } \\
\text { Masih kurangnya daya tarik } \\
\text { budaya harus ditingkatkan } \\
\text { dengan dukungan pemerintah } \\
\text { daerah (pariwisata unggulan) } \\
\text { dan pusat (KSPN) dengan } \\
\text { memaksimalkan manfaat TIC } \\
\text { sebagai media promosi yang } \\
\text { efektif dan efisien guna } \\
\text { menangkap peluang kunjung- } \\
\text { an wisatawan manca-negara } \\
\text { khususnya ketika di bukanya } \\
\text { penerbangan China - manado } \\
\text { (W1, P2,P3,P4,P5) }\end{array}$ \\
\hline Ancaman (Threats) & Strategi ST & egi WT \\
\hline $\begin{array}{l}\text { 1. Kebijakan pemerintah yang } \\
\text { tumpang tindih } \\
\text { 2. Travel warning } \\
\text { 3. Bencana alam } \\
\text { 4. Kerusakan lingkungan }\end{array}$ & $\begin{array}{l}\text { Keindahan alam yang harus } \\
\text { dijaga, sikap sadar wisata dan } \\
\text { peran serta pelaku usaha dalam } \\
\text { promosi harus lebih ditingkatkan } \\
\text { untuk mengurangi dampak } \\
\text { kebijakan pemerintah yang } \\
\text { tumpang tindih, kerusakan } \\
\text { lingkungan, bencana alam dan } \\
\text { travel warning (S1,S5,S6, T1-T4) }\end{array}$ & $\begin{array}{l}\text { 1. Perlu adanya koordinasi antar } \\
\text { sektor baik vertikal maupun } \\
\text { horizontal baik dalam proses } \\
\text { perencanaan, pelaksanaan dan } \\
\text { pengawasan pembangunan baik } \\
\text { fisik maupun non fisisk untuk } \\
\text { meminimalisir dampak dari } \\
\text { ancaman-ancaman yang ada } \\
\text { (W1-W6, T1-T4) }\end{array}$ \\
\hline
\end{tabular}

Sumber: Hasil Analisis SWOT, 2018 
Hasil analisis yang sudah dilakukan menunjukkan bahwa pariwisata kawasan Selat Lembeh Kota di Bitung berada pada posisi kuat dan berpeluang. Rekomendasi strategi yang diberikan adalah progresif, artinya pariwisata kawasan Selat Lembeh berada dalam kondisi prima dan mantap sehingga sangat dimungkinkan untuk terus dilakukan perluasan, pengembangan, pertumbuhan untuk mencapai kemajuan secara maksimal.

Kawasan pariwisata Selat Lembeh memiliki kekuatan (strength) untuk menarik kunjungan wisatawan baik wisatawan lokal bahkan wisatawan mancanegara. Daya tarik pariwisata kawasan Selat Lembeh yang meliputi keindahan dan keunikan alamnya khususnya keunikan bawah laut Selat Lembeh serta daya tarik destinasi atraksi buatan menjadi daya tarik utama wisatawan untuk berkunjung. Tingginya minat kunjungan wisatawan dapat dilihat dari jumlah kunjungan wisatawan yang dari tahun ketahun meningkat secara signifikan serta minat dan aktivitas investasi bidang pariwisata yang terus berkembang. Dan secara eksternal, pariwisata kawasan Selat Lembeh memiliki peluang (opportunities) untuk pengembangannya seperti masuknya Kawasan Selat Lembeh sebagai salah satu kawasan strategis pengembangan pariwisata nasional, kebijakan pemerintah pusat dan provinsi menjadikan sektor pariwisata sebagai sektor unggulan, kebijakan pemerintah membuka penerbangan langsung dari China ke Manado, ketersedian tehnologi informasi dan komunikasi sebagai sarana promosi yang efektif dan efisien, tingginya minat investasi bidang pariwisata, serta tingginya minat wisatawan. Dengan demikian menjadi tantangan bagi pemerintah Kota Bitung untuk mengembangkan pariwisata di kawasan Selat Lembeh untuk meningkatkan perekononomian masyarakat dan meningkatkan pendapatan daerah.

Pada kenyataanya dalam upaya pengembangan pariwisata Kawasan Selat Lembeh, disamping secara internal memiliki kekuatan tetapi juga terdapat kelemahan-kelemahan yang perlu dibenahi. Secara internal kelemahan kelemahan yang perlu dibenahi diantaranya; masih kurangnya daya tarik budaya, kurangnya sarana transportasi yang memadai, fasilitas pariwisata dan fasilitas umum yang tersedia belum memadai, masih rendahnya dukungan anggaran dari pemerintah daerah, kapasitas sumber daya manusia bidang pariwisata yang masih kurang, belum adanya regulasi pengelolaan destinasi pariwisata yang jelas ,serta tersedianya pelaku pariwisata yang memiliki standarisasi dan sertifikasi masih kurang.

Sementara secara eksternal juga terdapat berbagai ancaman (treath) yang mesti diantisipasi seperti kebijakan pemerintah yang menetapkan kawasan Selat Lembeh sebagai kawasan pengembangan international Hub Port dan industri, perusakan lingkungan, pencemaran, dan isue stabilitas keamanan.

kebijakan pemerintah dalam perecanaan pembangunan nasioal yang menetapkan kawasan Selat Lembeh sebagai International hub port dan kawasan industri sementara Kawasan ini dalam kenyataannya juga memiliki fungsi dalam pengembangan pariwisata di Kota Bitung. Kedua kebijakan ini sangat sulit diterapkan secara bersamaan mengingat dampak dari international hub port dan industri menyebabkan adanya conflict of interest yang cenderung bersifat merusak lingkungan jika tidak ditangani dengan baik, sementara pariwisata yang ada di Kawasan Selat Lembeh mengandalkan daya tarik alam/lingkungan. Demikian juga dengan ancaman kerusakan lingkungan, dimana keunikan bawah laut Selat Lembeh terancam keberadaannya akibat ulah oknum-oknum yang tidak bertanggung jawab serta ancaman isue stabilitas keamanan nasional juga sangat mempengaruhi kunjungan wisatawan mancanegara.

Pengembangan pariwisata akan memberikan dampak positif bagi perkembangan perekonomian suatu daerah karena mencakup segi - segi yang amat luas dan menyangkut berbagai segi kehidupan dalam masyarakat.

Dengan memperhatikan berbagai potensi, kekuatan dan peluang yang ada maka dipandang perlu untuk mengembangkan pariwisata kawasan Selat Lembeh kota Bitung sebagai salah satu primadona pariwisata yang akan menjadi lokomotif untuk menggerakan perekonomian untuk kesejahteraan masyarakat.

Pengembangan pariwisata berkaitan erat dengan banyak aspek dan sektor termasuk didalamnya berkaitan erat dengan pengaruh peran masyarakat. Peran masyarakat dalam upaya pengembangan pariwisata sangat penting dalam arti yang seluas - luasnya, dimana 
pengembangan pariwisata melibatkan masyarakat karena penyelenggaraan pariwisata diarahkan untuk mewujudkan pemerataan pendapatan dan kesempatan berusaha maka pelaksanaan berbagai usaha pariwisata yang dilakukan dapat saling mengisi, saling berkaitan dan saling menunjang satu sama lainnya.

Sesuai dengan konsep pengembangan pariwisata Kota Bitung yang tertuang dalam RIPARKOT Kota Bitung, pengembangan pariwisata adalah pengembangan yang berbasis pada pemberdayaan masyarakat. Dimana masyarakat terlibat langsung dan menjadi tujuan dari manfaat pengembangan pariwisata itu sendiri. Masyarakat terlibat dalam kegiatan pariwisata baik secara langsung maupun tidak langsung. Secara langsung masyarakat terlibat sebagai pelaku pariwisata baik pengusaha maupun pekerja dibidang pariwisata sedangkan keterlibatan secara tidak langsung adalah kehidupan masyarakat itu sendiri dalam berbagai sendi kegiatannya memberikan pengaruh terhadap lingkungan pariwisata.

Salah satu peran masyarakat dalam pengembangan pariwisata sesuai panduan Sadar wisata untuk masyarakat umum, Direktorat Jenderal Pariwisata, Seni dan Budaya (1988) adalah dengan mewujudkan suasana yang kondusif bagi lingkungan pariwisata yang memenuhi unsur -unsur Sapta Pesona. Unsur - unsur Sapta Pesona meliputi; aman, tertib, bersih, sejuk, indah, ramah tamah dan kenangan. Peran masyarakat lainnya adalah masyarakat sebagai pelaku pariwisata artinya masyarakat terlibat langsung baik sebaik pengusaha, pengelola dan pekerja dalam industri pariwisata.

Pariwisata yang melibatkan lintas sektor memerlukan koordinasi yang sangat kuat karena pengembangan pariwisata yang tujuannya memberikan pelayanan terbaik untuk memuaskan para wisatawan demi peningkatan kunjungan wisatawan. Karena itu pengembang-an pariwisata tidak hanya membenahi objek pariwisata saja tetapi juga membenahi berbagai unsur pendukungnya yang meliputi 3A yaitu atraksi, aksesibilitas dan amenitas.

Pembangunan pariwisata menjadi tanggung jawab semua pemangku kepentingan disamping masyarakat, pemerintah dan swasta. Pemerintah melaksanakan tugas pembangunan wilayahnya yang menjadi tanggung jawabnya yang meliputi pembangunan berbagai sektor fisik maupun non fisik baik secara langsung maupun tidak langsung yang berkaitan dengan pembangunan dan pengembangan pariwisata. Pemerintah juga berkewajiban untuk mengkoordinir, memfasilitasi dan mendorong pemangku kepentingan untuk berpartisipasi secara aktif dalam upaya pembangunan dan pengembangan pariwisata.

Pemerintah memberikan kemudahan investasi bagi industri pariwisata, merangsang pertumbuhan UKM bidang pariwisata, merangsa-ng tumbuh kembang pelaku seni budaya, pemerintah bersama pihak swasta bersama - sama dalam pelaksanaan Coorporate Social responsibility perusahan untuk mengembangkan pariwisata, sistem alokasi anggaran dalam APBD yang lebih fokus pada pembangunan bidang - bidang yang berkaitan langsung dengan pariwisata seperti pembangunan sarana dan prasarana pariwisata, peningkatan kapasitas sumber daya manusia bidang pariwisata serta peningkatan promosi pariwisata.

\section{KESIMPULAN DAN SARAN}

\section{Kesimpulan}

Dari hasil penelitian dan pembahasan maka dapat disimpulkan bahwa pengembangan pariwisata kawasan Selat Lembeh di Kota Bitung berdasarkan hasil analisis SWOT yang telah dilakukan berada di kuadran pertama antara peluang eksternal dan kekuatan internal. Strategi utama dalam mengembangkan pariwisata Kawasan Selat Lembeh yang harus dilaksanakan adalah dengan mengembangkan dan meningkatkan faktor Atraksi, Aksesibilitas dan Amenitas sebagai berikut:

1. Menjaga Keindahan dan keunikan alam Selat Lembeh sebagai daya tarik utama dan menambah objek daya tarik buatan yang baru.

2. Melengkapi dan meningkatkan fasilitas umum dan fasilitas pariwisata serta sarana dan prasarana yang ada.

3. Memanfaatkan dengan cerdas teknologi informasi komunikasi sosial media sebagai sarana promosi yang murah dan efisien. 


\section{Saran}

Adapun saran dalam penelitian ini adalah sebagai berikut:

1. Perlu diambil langah - langkah strategis untuk mengembangkan pariwisata di kawasan Selat Lembeh melalui pengembangan faktor Atraksi, Aksesibilitas dan Amenitas dengan memanfaatkan kekuatan dan peluang sebagai strategi utama untuk mengembangkan pariwisata di Kawasan Selat Lembeh.

2. Perlu adanya koordinasi dan konsultasi antar berbagai pemangku kepentingan yaitu masyarakat, swasta, pemerintah baik vertikal maupun horisontal termasuk antar SKPD (satuan kerja pemerintah daerah) dalam pelaksanaan pembangunan agar pelaksanaan pembangunan pariwisata di kawasan Selat Lembeh lebih terarah, efisien dan tepat sasaran.

3. Pemerintah Kota Bitung harus lebih berperan aktif dalam pembangunan pariwisata sesuai prioritas program yang dicanangkan, yang tercermin sejak dari perencanaan yang tepat guna dan tepat sasaran diikuti dengan alokasi anggaran untuk pembiayaan program/kegiatan terkait kepariwisataan dalam APBD.

\section{DAFTAR PUSTAKA}

Badan Pusat Statistik Kota Bitung. 2016. Bitung Dalam Angka 2016.

Dinas Pariwisata Kota Bitung, 2017. A Wonderful City from North Sulawesi, Bitung., Tourism Book. Pemerintah Kota Bitung.

Dinas Pariwisata Kota Bitung. 2017. Profil Pariwisata Kota Bitung.

Peraturan Pemerintah No 50 Tahun 2011 Tentang Rencana Induk pembangunan Pariwisata Nasional. 